Journal home page: http://chimie-biologie.ubm.ro/carpathian_journal/index.html

\title{
EFFECTS OF SMOKING ON THE NUTRITIONAL COMPOSITION OF FLESH AND OIL CHEMISTRY OF ATLANTIC MACKEREL (SCOMBER SCOMBRUS) OIL
}

\author{
Ejiofor U. Emmanuel ${ }^{1,2 凶}$, Ebhohon O. Shirley ${ }^{1}$, Nwuke P. Chinedu ${ }^{1}$, Nweje-Anyalowu Paul ${ }^{2}$, \\ Onah J. Chibuka ${ }^{3}$, Onodugo Chinemelum Adaora ${ }^{5}$, Udoka I. Edward ${ }^{6}$, Kanu Michael ${ }^{4}$, Maureen \\ C. Chukwu ${ }^{1}$ and Omeh Yusuf Ndukaku ${ }^{1}$ \\ ${ }^{1}$ Department of Biochemistry, College of Natural Sciences, Michael Okpara University of Agriculture, \\ Umudike, Umuahia, Abia State, Nigeria \\ ${ }^{2}$ Department of Biochemistry, Faculty of Science, Clifford University, Owerrinta, Abia State, Nigeria \\ ${ }^{3}$ Department of Science Laboratory Technology, Institute of Management Technology, Enugu, Enugu \\ State, Nigeria. \\ ${ }^{4}$ Medical Laboratory Sciences, School of Health Technology, Aba, Abia State, Nigeria. \\ ${ }^{5}$ Department of Biochemistry, Federal University, Oye-Ekiti, Ekiti State, Nigeria. \\ ${ }^{6}$ Centre for Molecular Biosciences and Biotechnology, Michael Okpara University of Agriculture, \\ Umudike, Umuahia, Abia State, Nigeria \\ 凶ejioforemmanuelbiz@gmail.com \\ https://doi.org/10.34302/crpjfst/2020.12.3.11
}

Article history:

Received:

13 December 2019

Accepted:

18 July 2020

Keywords:

Fish;

Roasting;

Oil;

Fatty acids;

Proteins.

\section{ABSTRACT}

Fish constitute a major part of human diet. It a good source of proteins, lipids and minerals. Fishes are processed before they are consumed, to offer palatability and preservation. The study investigated the effects of processing on the nutritional properties, in vitro antioxidant capacity and fatty acid profile of oil. Processing methods used were sun drying and smoking methods. On milled fish samples, nutritional analysis such as minerals and proximate analysis were performed using standard protocols. After processing, oil from Scomber scombrus as extracted using soxhlet extractor and n-hexane as solvent. In vitro antioxidant assay, fatty acid profile and physiochemical parameters of the oil performed. Result showed protein, fat, sodium and fibre were significantly $(\mathrm{P}<0.05)$ higher in sundried sample compared to smoked. Saponification value, peroxide value and iodine value were significantly $(\mathrm{P}<0.05)$ higher in oil obtained from smoked fish when compared to sundried. Fatty acid profile showed the presence of four fatty acids. From the result of this study, it can be concluded that smoking affected the nutritional properties of the fishes, especially the oil chemistry.

\section{Introduction}

The roles played by fish in human nutrition has been fully established (Tufan et al., 2016). They are good sources of minerals, amino acids (Oluwaniyi et al., 2010), vitamins and lipids (Dobreva et al., 2011). The oils are rich in omega-3 fatty acids (Venugopal, 2009), and have been have been implicated to be useful in managing many disease conditions such as obesity, diabetes, cancer (Gogus and Smith, 2010).

The fish Atlantic mackerel known scientifically as Scomber scrombus is readily available in the Atlantic. It is highly consumed in Nigeria, considering that it is cheaper and offers good source of protein and amino acids 
(Kim and Lall, 2000), but first undergoes processing to be fit for consumption. Processing methods used in Nigeria's traditional system includes sun drying, boiling, frying and roasting (Oluwaniyi et al., 2010).

Generally, it is known that method of processing food items has impact on the nutritional property of the food materials. Some processing method leads to loss of vital components of the food, while others may improve the nutritional quality of the food item. Studies by Oluwaniyi et al., (2010), reported that processing (boiling and roasting) had a desirable effect on the amino acids constituents of fishes.

In Nigeria, fish smoking is a very common practice, as it is seen to preserve the fish for a longer time than any other traditional method. The study therefore investigates the effect of smoking on the fatty acids profile, antioxidant properties of oil obtained from Horse Mackerel, and looks at how this processing method affects it nutritional properties.

\section{Materials and methods}

\subsection{Procurement of the raw material} Fish sampling and handling

The fish samples (Scomber scrombus) locally called titus were purchased from a commercial market in Umuahia, Abia State, Nigeria. They were bought iced and transported to the Department of Biochemistry, Michael Okpara University, Umudike, Abia State in an ice pack. The fish samples were washed in running water, and cut into parts with a knife. The head region was discarded and the remaining parts were properly washed again to remove the presence of blood.

\section{Sample treatment}

The fish (wet) was divided into two sections. Part A served as control and was dried under the sun for three days in a locally made iron fish basket covered with net to prevent the presence of flies, while part B which served as the test group was smoked. Smoking was achieved using fire wood and wood shavings. Briefly, the firewood and wood shavings were burnt to generate smoke through a channel (iron drum). The fishes placed on an iron mesh was kept on top of the drum. Smoking was achieved for seven hours. The samples were milled after processing and stored in air tight container.

\section{Proximate analysis of milled sample}

Proximate analysis was determined by the method described by AOAC (1990)

\section{Mineral estimation of milled sample}

Minerals were estimated by the method described by James, 1995.

\section{Oil extraction}

Dried fish samples were milled into fine powder and oil extraction was achieved using nhexane as solvent in a soxhlet extractor.

\section{Physicochemical property of oil}

Physiochemical analysis was determined by the method described by AOAC (1990). Colour of the obtained oils were determined by physical eye observation. Five persons allowed to sight the sample and make colour observation.

\section{In vitro antioxidant potentials of oil}

DPPH scavenging potentials of the oil was determined by the method described by Manzocco et al., 1998. Reducing power of the oil was determined by the method described by Oyaizu, 1986.

\section{Fatty acid characterization}

Fatty acid characterization of the oil was determined by the method described by Ezeagu et al., 2005.

\section{Statistical analysis}

Data obtained was statistically analysed. For data containing two variables, student $\mathrm{T}$ - test was employed, while data with three variables was analysed using analysis of variance ANOVA). Significant difference was set at $95 \%$ confidence level. Result was reported as mean \pm S.D. 


\section{Results and discussions}

\subsection{Results}

Table 1. Proximate composition of fish samples

\begin{tabular}{|l|l|l|}
\hline Parameter & Sundried fish & Smoked fish \\
\hline Protein (\%) & $54.08 \pm 0.22^{*}$ & $52.09 \pm 0.07$ \\
\hline Fat $(\%)$ & $22.30 \pm 0.21^{*}$ & $20.20 \pm 0.03$ \\
\hline Fibre (\%) & $7.76 \pm 0.03^{*}$ & $7.18 \pm 0.02$ \\
\hline Moisture (\%) & $6.52 \pm 0.31$ & $7.33 \pm 0.10^{*}$ \\
\hline Ash (\%) & $6.79 \pm 0.03$ & $7.12 \pm 0.11^{*}$ \\
\hline Carbohydrate (\%) & $5.45 \pm 0.02$ & $5.41 \pm 0.01$ \\
\hline
\end{tabular}

Values reported as mean \pm S.D of triplicate determinations. ${ }^{(*)}$ indicates significant difference at $95 \%$ confidence level.

Table 2. Mineral estimation of fish samples

\begin{tabular}{|l|l|l|}
\hline Parameter & Sundried fish & Smoked fish \\
\hline Sodium $(\mathrm{mg} / 100 \mathrm{~g})$ & $9.03 \pm 0.02$ & $9.20 \pm 0.01^{*}$ \\
\hline Potassium $(\mathrm{mg} / 100 \mathrm{~g})$ & $5.35 \pm 0.16$ & $5.38 \pm 0.01$ \\
\hline Calcium $(\mathrm{mg} / 100 \mathrm{~g})$ & $2.40 \pm 0.00$ & $2.44 \pm 0.01$ \\
\hline Phosphorous $(\mathrm{mg} / 100 \mathrm{~g})$ & $6.41 \pm 0.01$ & $6.44 \pm 0.01$ \\
\hline Magnesium $(\mathrm{mg} / 100 \mathrm{~g})$ & $6.10 \pm 0.00$ & $6.04 \pm 0.00$ \\
\hline
\end{tabular}

Values reported as mean+S.D of triplicate determinations. ${ }^{(*)}$ indicates significant difference at $95 \%$ confidence level.

Table 3. Physicochemical properties of fish oil

\begin{tabular}{|l|l|l|}
\hline Parameter & Sundried fish & Smoked fish \\
\hline Colour & Opaque & Dark \\
\hline Saponification value & $108.16 \pm 0.03$ & $135.19 \pm 0.00^{*}$ \\
\hline Peroxide value & $2.01 \pm 0.01$ & $2.42 \pm 0.01^{*}$ \\
\hline Iodine value & $118.72 \pm 0.01$ & $128.63 \pm 0.01^{*}$ \\
\hline
\end{tabular}

Values reported as mean+S.D of triplicate determinations. ${ }^{(*)}$ indicates significant difference at $95 \%$ confidence level.

Table 4. DPPH scavenging activity of oil obtained from fish samples

\begin{tabular}{|l|l|l|l|}
\hline Concentration $(\mathrm{mg} / \mathrm{ml})$ & $\begin{array}{l}\text { Sundried fish } \\
(\% \text { inhibition})\end{array}$ & $\begin{array}{l}\text { Smoked fish } \\
(\% \text { inhibition })\end{array}$ & $\begin{array}{l}\text { Vitamin C } \\
(\% \text { inhibition })\end{array}$ \\
\hline 10 & $14.13 \pm 0.02^{\mathrm{b}}$ & $10.10 \pm 0.07$ & $50.12 \pm 0.01^{\mathrm{a}}$ \\
\hline 20 & $16.92 \pm 0.02^{\mathrm{b}}$ & $12.01 \pm 0.00$ & $55.74 \pm 0.02^{\mathrm{a}}$ \\
\hline 40 & $19.33 \pm 0.01^{\mathrm{b}}$ & $14.02 \pm 0.00$ & $78.10 \pm 0.00^{\mathrm{a}}$ \\
\hline 80 & $24.53 \pm 0.00^{\mathrm{b}}$ & $18.24 \pm 0.00$ & $80.13 \pm 0.04^{\mathrm{a}}$ \\
\hline 100 & $28.55 \pm 0.00^{\mathrm{b}}$ & $20.21 \pm 0.27$ & $90.54 \pm 0.13^{\mathrm{a}}$ \\
\hline
\end{tabular}

Values reported as mean + S.D. ${ }^{(a)}$ indicates significantly higher $(P<0.05)$ than the sundried and smoked fish group. ${ }^{(b)}$ indicates significantly higher $(P<0.05)$ than the smoked fish group. 
Table 5.Reducing power activity of oil obtained from fish samples

\begin{tabular}{|l|l|l|l|}
\hline Concentration $(\mathrm{mg} / \mathrm{ml})$ & $\begin{array}{l}\text { Sundried fish } \\
(\text { OD at 700nm) }\end{array}$ & $\begin{array}{l}\text { Smoked fish } \\
(\text { OD at 700nm) }\end{array}$ & $\begin{array}{l}\text { Vitamin C } \\
(\text { OD at 700nm) }\end{array}$ \\
\hline 10 & $0.71 \pm 0.00^{\mathrm{b}}$ & $0.51 \pm 0.00$ & $1.42 \pm 0.00^{\mathrm{a}}$ \\
\hline 20 & $0.78 \pm 0.00^{\mathrm{b}}$ & $0.59 \pm 0.00$ & $1.56 \pm 0.00^{\mathrm{a}}$ \\
\hline 40 & $0.90 \pm 0.00^{\mathrm{b}}$ & $0.68 \pm 0.00$ & $1.72 \pm 0.00^{\mathrm{a}}$ \\
\hline 80 & $1.10 \pm 0.00^{\mathrm{b}}$ & $0.73 \pm 0.00$ & $1.82 \pm 0.00^{\mathrm{a}}$ \\
\hline 100 & $1.29 \pm 0.00^{\mathrm{b}}$ & $0.81 \pm 0.00$ & $1.88 \pm 0.01^{\mathrm{a}}$ \\
\hline
\end{tabular}

Values reported as mean+S.D. ${ }^{(a)}$ indicates significantly higher $(P<0.05)$ than the sundried and smoked fish group. ${ }^{(b)}$ indicates significantly higher $(P<0.05)$ than the smoked fish group.

Table 6. Fatty acid profiles of fish oil samples

\begin{tabular}{|l|l|l|}
\hline $\begin{array}{l}\text { Fatty acid } \\
\text { \% composition) }\end{array}$ & Sundried fish & Smoked fish \\
\hline Myristic (C14:0) & 12.84 & 16.98 \\
\hline Palmitic (C16:0) & 39.83 & 41.29 \\
\hline Oleic (C18:1) & 34.89 & 34.61 \\
\hline Linoleic (C18:2) & 8.28 & 11.24 \\
\hline
\end{tabular}

\subsection{Discussion}

Generally, fish processing has been shown to alter nutritional values of fishes, and this effect is dependent on the method of processing (Oluwaniyi et al., 2010). The proximate composition of fish samples is presented in Tab. 1. Protein, fat and fibre composition was significantly $(P<0.05)$ higher in the sundried samples compared to smoked sample. Moisture and ash content was significantly $(P<0.05)$ higher in the smoked samples compared to the sundried samples. From the result obtained from this study, it becomes clear that smoking lowered the composition of protein, fat and fibre in the fish samples. Mathew et al., (2014), reported that smoking affects nutritional component of fishes.

Result for sodium concentration was significantly $(P<0.05)$ higher in the smoked sample when compared to the sundried sample. However, all other minerals were not affected by smoking as shown in Tab. 2. The value reported for sodium in this study is like the value reported by Mathew et al., (2014).

The colour of the oil obtained from the smoked fish showed great deviation. Colour report from scoring individuals showed that the fish oil was black in colour as against the sundried fish oil wish was opaque and clear in colour. This could be because of large amount of carbon emitted from the smoke that was deposited on the fish samples before oil extraction. Saponification, peroxide and iodine value was also significantly $(P<0.05)$ higher in the oil obtained from smoked samples when compared to sundried samples. The increase in saponification, peroxide and iodine value can be to the damage and oxidation caused by hydrocarbon compounds present in the smoke. Emmanuel et al., (2018), reported that hydrocarbons from fossil fuels processing can generate oxidants that damage nutritional oils.

Result for in vitro antioxidant capacity of the oil showed that oil from sundried samples was more potent than smoked fish oil. DPPH scavenging activity and reducing power activity was significantly $(\mathrm{P}<0.05)$ higher in sundried fish samples when compared to smoked fish samples, although Vitamin C used as standard had the highest activity. This indicates that sun drying method preserved more antioxidant in the oil than smoking. Also, smoking can generate free radicals in the oil which is likely to reduce 
the number of antioxidants present in the oil sample.

Result for fatty acids showed the same type of fatty acids in both oil samples, however few deviations were observed in the concentration of myrsitic and linoleic fatty acids. This indicates that smoking does not affect fatty acid profile of oil.

\section{Conclusions}

From the result of this study, it can be concluded that smoking affects the nutritional composition of fishes, and affects majorly the oils obtained from the fishes negatively, which may in turn affect the application of such oil in medicine.

\section{References}

AOAC. (1990). Official methods of analysis of the AOAC, 15th ed. Methods 932.06, 925.09, 985.29, 923.03. Association of official analytical chemists. Arlington, VA, USA.

Dobreva A.D., Merdzhanova A., Stancheva M. \& Makedonski L. (2011). Fatty acid profile and Vitamin A and E content in Horse Mackerel (Trachurus mediterraneus). Asian Chemistry Letters, 15, 1

Emmanuel E., Ebhohon S., Adanma O., Bliss O., Atasie O., Ajah O., Kanu M. \& Ndukaku O. (2018). Fatty acids composition profile evaluation of palm oil in crude oil polluted environment. Asian Journal of Agriculture and Biology, 6(3),373-378

Gogus, U. \& Smith, C. (2010). n-3 Omega fatty acids: a review of current knowledge. International Journal of Food Science and Technology, 45 (3), 417-436

James, C.S., 1995. Analytical Chemistry of Foods. 1st Edn., Chapman and Hall, New York, ISBN: 978-1-4613-5905-0, 178.

Kim, J.D. \& Lall, S.P. (2000). Amino acid composition of whole body tissue of Atlantic halibut (Hippoglossus hippoglossus), yellowtail flounder (Pleuronectes ferruginea) and Japanese flounder (Paralichthys olivaceus). Aquaculture, 187, 367-373.
Manzocco, L., Anese, M. \& Nicolli, M.C. (1998). Antioxidant properties of tea extract as affected by pircasing. Lebens-mittelWissen-Schaft Und-Technology 31(7-8), 694-698.

Mathew, O.A., Bako, S.N., Odiba, J.O., Ruth O.A. \& Garbunga G.Y. (2014). Compositional evaluation of local smoked Nigerian Mackerel (Scomber scombrus). Food Science and Quality Management, 24: 42- 50

Oluwaniyi, O.O., Dosumu, O.O. \& Awolola, G.V. (2010). Effect of local processing methods (boiling, frying and roasting) on the amino acid composition of four marine fishes commonly consumed in Nigeria. Food Chemistry, 123: 1000-1006

Oyaizu, M. (1986). Studies on product of browning reactions antioxidative activities of products of browning reaction prepared from glucose amine. Japanese Journal of Nutrition and Dietetics, 44, 307-315.

Tufan, B., Balcık Misır, G. \& Kose, S. (2018). Comparison of seasonal fatty acid composition in relation to nutritional value of three commercial fish species caught from different zones of Eastern Black Sea. Aquatic Sciences and Engineering, 33(1), 11-19.

Venugopal, V. (2009). Marine Products for Healthcare: Functional and Bioactive Nutraceutical Compounds from the Ocean. CRC Press, Baco Raton, USA. 